\title{
PHYSIOLOGICAL AND BIOCHEMICAL CHARACTERIZATION OF THE ASSAI PALM (Euterpe oleracea MART.) DURING SEED GERMINATION AND SEEDLING GROWTH UNDER AEROBIC AND ANAEROBIC CONDITIONS ${ }^{1}$
}

José Francisco de Carvalho Gonçalves², Renata Braga Souza Lima², Andreia Varmes Fernandes², Eduardo Euclydes de Lima e Borges ${ }^{3}$ e Marcos Silveira Buckeridge ${ }^{4}$

\begin{abstract}
Physiological and biochemical aspects of assai palm during seed germination and early seedling growth were investigated. Seeds collected from plants growing in flooded and upland forests were used to determine the influence of normoxic (aerobic) and anoxic (anaerobic) conditions in germination and the initial and average time of development in the roots and shoots. After 75 days, seedlings germinated under normoxia were transferred to trays and submitted to flooding. Seed reserves (lipids, proteins, soluble sugars and starch) were monitored for quiescent and germinated seeds maintained under normoxic and anoxic conditions, as well as after 5, 10 and 20 days of seedling growth. Alcohol dehydrogenase (ADH) activity was quantified in roots and leaves of seedlings without or with flooding (partial and total). Seeds were not able to germinate under anoxia. Different strategies of storage mobilization of lipids, proteins, soluble sugars and starch were observed in seeds of each environment. ADH activity was induced by anoxia, with the highest level observed in the leaves. This study showed that, under normoxic conditions, the best developmental performance of assai palm seeds, from flooded or upland forest areas, during germination was associated with primary metabolites mobilization and seedling flooding tolerance with increased ADH activity. We conclude that the assai palm is well adapted to the anoxic conditions provoked by flooding.
\end{abstract}

Key words: Alcohol dehydrogenase, Anoxia and normoxia and Storage mobilization.

\section{CARACTERIZAÇÃO FISIOLÓGICA E BIOQUÍMICA DURANTE A GERMINAÇÃO DE SEMENTES E O CRESCIMENTO DE PLÂNTULAS DE AÇAÍ (Euterpe oleracea MART.) SOB CONDIÇÕES AERÓBICA E ANAERÓBICA.}

\begin{abstract}
RESUMO - Aspectos fisiológicos e bioquímicos durante a germinação de sementes e crescimento inicial de plântulas de açaí foram investigados. Sementes coletadas de plantas crescendo na várzea e na terra firme foram utilizadas para determinar a influência das condições de normoxia (aeróbica) e de anoxia (anaeróbica) na germinação e no tempo inicial e médio do desenvolvimento da raiz e parte aérea. Após 75 dias, plantas germinadas sob normoxia foram transferidas para condições de alagamento. A quantificação das reservas da semente (lipídios, proteínas, açúcares solúveis e amido) foi monitorada em sementes quiescentes e germinadas em condições de normoxia e anóxicas, bem como após 5, 10 e 20 dias de crescimento das plantas. A atividade da enzima desidrogenase alcoólica ( $A D H$ ) foi quantificada em raízes e folhas de plantas submetidas ao alagamento (parcial ou total) ou sem alagamento. As sementes não germinaram em condições de anoxia. Nas sementes, diferentes estratégias de mobilização de reservas (lipídios, proteínas, açúcares solúveis e amido) foram observadas, nas condições estudadas. A atividade da ADH foi induzida em condições de anoxia, sendo maior a atividade observada nas folhas. Este estudo demonstrou que, sob condições aeróbicas, o melhor desempenho das sementes de açaí, da várzea ou em terra firme, durante a germinação foi associado à mobilização de reservas e à tolerância das plântulas ao alagamento com o aumento da atividade da ADH. Concluiu-se que a palmeira açaí é a planta bem adaptada às condições de anoxia provocadas pelo alagamento.
\end{abstract}

Palavras-chave: Desidrogenase alcoólica, Anoxia e normoxia e Mobilização de reservas.

\footnotetext{
${ }^{1}$ Recebido em 05.08.2008 e aceito para publicação em 25.08.2010.

${ }^{2}$ Instituto Nacional de Pesquisas da Amazônia, Laboratório de Fisiologia e Bioquímica Vegetal, Manaus-AM, Brasil. E-mail: <jfc@inpa.gov.br>, <renatabsl@hotmail.com>e < varmes@inpa.gov.br>.

${ }^{3}$ Universidade Federal de Viçosa, Departamento de Engenharia Florestal, UFV, Brasil. E-mail: <elborges@ufv.br>.

${ }^{4}$ Universidade de São Paulo, Departamento de Botânica, São Paulo-SP, São Paulo-SP, Brasil. E-mail: <msbuck@usp.br>.
} 


\section{INTRODUCTION}

The periodic flooding in the central Amazonian region is responsible for deep changes in the environmental conditions. In this region, approximately $300,000 \mathrm{~km}^{2}$ are covered with flooded forests; classified generically as seasonally-flooded and permanently flooded forests, which occupy areas of 200,000 and $100,000 \mathrm{~km}^{2}$, respectively (Junk, 1993). However, the construction of hydropower stations has considerably enlarged the extension of areas occupied by water, provoking harmful environmental effects to the Amazonian rainforest (Fearnside, 2002). Besides the flooding of large areas, hydropower construction leads to the establishment of roads and/or power lines, which provokes fragmentation and destruction of the forest. Therefore, the establishment of measures able to help to decrease the environmental impacts of hydropower development are highly required.. In this context, plants that show adaptations to environmental flooding are of great importance for the restoration of areas affected by hydropower dams.

According to Parolin et al. (2004), combinations of adaptations of seedling growth and development and seed germination result in a variety of growth strategies of trees of the central Amazonian regions. These lead to specific species distributions and "zonations" along the flooding gradient, and within Amazonian floodplain systems with different environmental conditions, depending on the quality of the flooding rivers. Regarding seed germination, Wittmann et al. (2007) concluded that the contact with river water did not disturb it but, on the contrary, enhanced germination in the species Salix martiana, Pseudobombax munguba, Laetia corymbulosa and Vitex cymosa.

Among Amazonian plants, the assai palm (Euterpe oleracea Mart.); one of many commercially important species endemic to the region, is distinguished by its high level of tolerance to local abiotic stress conditions; being capable of adapting its growth to seasonallyflooded soils (Oliveira et al., 2002). As observed for some plants growing under flooding conditions, Palmae plants develop, in their roots, special structures called pneumatophores (Calbo et al., 1998).

Plant oxygen status can be defined as normoxic (aerobic conditions), hypoxic (low oxygen availability), and anoxic (anaerobic conditions). Plant species growing under anoxia exhibit biological changes that induce anatomical, biochemical and physiological adaptations (Waldhoff et al., 1998; Moraes et al., 2001; Souza and Sodek, 2002). In contrast, species sensitive to flooding may exhibit some or all of the following responses: interruption of vegetative and reproductive growth; reduction of stomatal conductance; leaf chlorosis and abscission; nutritional deficiency, accumulation of toxic substances in the roots; and even plant death (Carvalho and Ishida, 2002; Arruda and Calbo, 2004).

Under flooding stress, the composition, quantity and mobilization of seed reserves (lipids, proteins, soluble sugars, and starch) and the enzyme activities related to ATP production through glycolysis and fermentation are crucial for early seedling growth under anoxic conditions (Ricard et al., 1994; Dolferus et al., 2003). Proteins which are synthesized as specific responses to anaerobiosis are called the anaerobic polypeptides. Most of the known proteins accumulated in plants under anoxia are enzymes related to sucrose and starch degradation, glycolysis and ethanol fermentation (Liao and Lin, 2001). Among them, alcohol dehydrogenase $(\mathrm{ADH})$ is an enzyme that catalyzes the reduction of acetaldehyde to ethanol while oxidizing NADH to NAD ${ }^{+}$. In plants, increasing activity of this enzyme has been observed for a long time and is thought to be related to flooding (Crawford, 1967; Wignarajah et al., 1976). The formation of ethanol is thought to help the plant cell to alleviate the deleterious effects provoked by lactate accumulation (cytoplasmic $\mathrm{pH}$ acidification) (Bray et al., 2000).

Considering that the knowledge about the biochemical processes involved in seedling establishment are key to understanding how these plant species adapt to their respective environments, we tried to characterize the mobilization of storage compounds (starch, soluble sugar, lipids and proteins) and the activity of alcohol dehydrogenase during seed germination and seedling growth of E. oleraceae either under flooded or upland forests conditions.

\section{MATERIALS AND METHODS}

\subsection{Plant material, seed germination and seedling growth}

Seeds of assai palm were collected from 10 plants growing in flooded and upland forest conditions at the Pedro de Moura Base for Geologic Operations, 
$4^{\circ} 53^{\prime} \mathrm{S}$ and $65^{\circ} 11^{\prime} \mathrm{W}$ (Petrobras-BR), located $600 \mathrm{~km}$ from Manaus (AM) Brazil. Seeds were surface sterilized with $0.5 \%(\mathrm{v} / \mathrm{v})$ sodium hypochlorite for $10 \mathrm{~min}$ and then placed to germinate in trays containing washed sand. Seed germination was recorded during the following treatments: a) submergence (water level $\pm 4 \mathrm{~cm}$ ), and b) under normoxic conditions (control). For each treatment three replicates of 25 seeds were used. Germination tests were carried out at $30 \pm 2^{\circ} \mathrm{C}$ and relative air humidity of $90 \%$, considering botanical and technological criterion of germination (radicle emission or complete plant, respectively), according to Labouriau (1983) and Brasil (1992). Seeds of assai palm from flooded and upland forest areas were germinated (with or without flooding) and were monitored daily, for 75 days and the following variables were followed: a) Emergence velocity index (EVI), b) Initial germination time (IGT), c) Average germination time (AGT) and d) percentage of germination. Seventy five days after the beginning of the germination experiment, seedlings from seeds germinated under normoxia (seeds were not able to germinate under anoxia) were transferred, in three groups of 36 plants, to trays containing a mixture of sand and soil (1:1). To test the influence of normoxia and anoxia on the mobilization of reserves during early seedling growth, assai palm seedlings were submerged in a water level of $10 \mathrm{~cm}$ above the level of the seedlings.

\subsection{Extraction and quantification of seed compounds}

The amounts of lipids, proteins, and carbohydrates were monitored in quiescent and germinated seeds (75 days) with 5, 10 and, 20 days of growth of the seedlings. For the quantification of seed primary metabolites three replicates of seeds were tested for each environment. Unless otherwise stated, all the analyses were performed using dried plant material $\left(75^{\circ} \mathrm{C}\right)$. Lipid extraction was performed using the Soxhlet apparatus. Seeds and seedlings lipid contents were determined following the A.O.A.C recommendation (1984). Proteins were extracted according to Passos (1996) using the hot alcohol method. Protein concentration was determined according to Bradford (1976), using bovine serum albumin (BSA) as a standard. For soluble sugars determination, seeds were crushed with $95 \%$ (v/v) ethanol, following centrifugation at $3,500 \mathrm{xg}$, for $10 \mathrm{~min}$ at $25^{\circ} \mathrm{C}$. The supernatant was stored and the pellet was re-extracted with $80 \%(\mathrm{v} / \mathrm{v})$ ethanol $\left(60^{\circ} \mathrm{C}\right)$ and centrifuged as mentioned before (Buckeridge \& Dietrich, 1996). The supernatants were combined for the determination of soluble sugars, and the pellet suspended in $10 \mathrm{~mL}$ of $35 \%(\mathrm{v} / \mathrm{v})$ perchloric acid. After centrifugation, the supernatant was collected for the quantification of starch. Soluble sugars and starch were estimated by the anthrone technique $(625 \mathrm{~nm})$ using glucose as a standard $\left(\right.$ Sigma $\left.^{\circledR}\right)$ (Morris, 1948).

\subsection{Extraction and determination of alcohol dehydrogenase activity -ADH (E.C. 1.1.1.1)}

Enzyme activity was measured in leaves and roots of assai palm seedlings cultivated under the following conditions: a) control (without flooding), b) partial flooding ( $\pm 2 \mathrm{~cm}$, only roots submerged), and c) flooding ( $\pm 18 \mathrm{~cm}$, entire plant submerged). Leaves and roots were collected for enzyme extraction with three replicates from seedlings cultivated during 2, 4, 8 and 16 days. Plant material (1 g) was homogenized in $50 \mathrm{mM}$ Tris-HCl (pH 6.8) containing 2.5 mM magnesium chloride, $1 \mathrm{mMEDTA}, 0.15 \mathrm{ml}$ of glycerol, $0.5 \mathrm{ml}$ â-mercaptoethanol $2 \mathrm{mM}(\mathrm{v} / \mathrm{v})$ and distilled water to a final volume of $10 \mathrm{ml}$. After centrifugation ( $5000 \mathrm{x} \mathrm{g}, 10 \mathrm{~min}, 4^{\circ} \mathrm{C}$ ), aliquots of 100 il were added to the reaction medium containing 320 ìl of 50 mM Tris-HCl (pH 8.9), 100 ìl ethanol, 100 ì NAD ${ }^{+}\left(10 \mathrm{mg} \mathrm{ml}^{-1}\right)$, and distilled water to a final volume of $2.7 \mathrm{ml}$. After incubation at $30^{\circ} \mathrm{C}$ for $15 \mathrm{~min}$, the absorbance was monitored (Genway Instrument 6105, Essex, England) at 340 nm (Menezes Neto et al., 1995). ADH activity was assayed by following the reduction of $\mathrm{NAD}^{+}$. The assay was started by adding $0.040 \mathrm{ml}$ of $50 \%$ ethanol and $A_{340}$ was recorded every $30 \mathrm{~s}$ during $180 \mathrm{~s}$.

\subsection{Experimental design and statistical analysis}

The experimental design was completely randomized with three treatments and twelve replicates (seedlings). The results of the germination experiments and quantification of organic reserves were submitted to variance analysis (ANOVA) followed by the Tukey test (P d” 0.05), using Statistica for Windows Version 6 (StatSoft Inc., 2003 East 14 ${ }^{\text {th }}$ Street, Tulsa, OK, USA).

\section{RESULTS AND DISCUSSION}

Seventy five days after the beginning of the germination experiment, more than $95 \%$ germination was reached in all treatments (Table 1 ). We obtained 145 seedlings after germination under normoxic conditions, 73 of them being from plants growing in flooded environments and 72 from plants growing in upland forests conditions. When submitted to anoxic

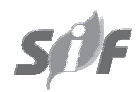

Revista Árvore, Viçosa-MG, v.34, n.6, p.1045-1053, 2010 
conditions assai palm seeds did not germinate. However, it is known that the assai palm occurs in flooded environments, and probably begins the germination process under conditions of normoxia during the dry period (Menezes Neto et al., 1995). This suggests that under anoxic conditions, the seeds of assai palm are likely to be unable to synthesise and/or activate enzymes necessary for seed germination. Okamoto \& Joly (2000) studying the germination of Inga sessilis (Vell.) Mart. seeds submitted to conditions of normoxia, hypoxia, and anoxia, found that $40 \%$ of the seeds germinated under hypoxia.

\subsection{Comparison between seed germination of assai from different environments}

Assai palm seeds collected in upland forests showed the highest index of emergence velocity (1.9), the shortest time for radicle emergence (6 days), as well as the lowest values for average time of radicle and shoots emission (17 and 22 days, respectively). In comparison, seeds collected in the flooded area showed an emergence velocity index of 0.8 , an initial time for germination of 16 days and an average time of approximately 34 and 46 days for the roots and shoots emission, respectively (Table 1 ). Nevertheless, it is important to stress that there was no difference in the final percentage of germination between seeds collected in flooded areas (98\%) or upland forests (96\%). Under natural conditions in the forest, assai seeds can take 1-11 months to germinate. Under laboratory conditions the percentage of seed germination can reach ca. $90 \%$, but under natural conditions no more than $60 \%$ of assai seeds are able to germinate (Bovi et al., 1989). Our results are consistent with the hypothesis that faster seed germination of flood-intolerant seeds might be a strategy with which plants take advantage of favorable conditions that lead to seedling establishment.

During seed germination, carbon can be mobilized either in the form of carbohydrates or lipids, starch being one of the most important storage polysaccharides, followed by the cell wall polysaccharides (Buckeridge et al., 2004). Table 2 shows that the concentration of starch was higher in assai seeds collected in flooded than in upland forests. A possible explanation for this difference is that plants growing in a flooded habitat could have accumulated more reserves (carbohydrates) as an evolutionary adaptation. This is likely to have happened because the change from aerobic to anaerobic respiration can severely affect the availability of energy in the plant (Junk, 1989; Drew, 1997; Figueiredo et al., 2001; Pontes et al., 2002).

Table 2 shows that in the upland forests, some starch mobilization occurred, with the decrease around $40 \%$ after germination. In the flooded area, however, no difference was observed in starch levels. This suggests a possible role of starch as one of the carbon storage compounds in assai seeds.

The concentration of soluble sugars was much higher in drier than in flooded areas, whereas lipids were not different in seeds from the two environments. However, for proteins a decrease of approximately

Table 1 - Comparison between assai palm seed germination from different environments under normoxic conditions, using botanical and technological criteria. Emergence velocity index (EVI), Initial germination time (IGT), Average germination time (AGT) and percentage of germination.

Tabela 1 - Comparação entre a germinação de sementes de açaí de deferentes ambientes sob condições de normoxia, usando os critérios botânico e tecnológico. Índice de velocidade de germinação (IVE), tempo inicial de germinação (TIG), tempo médio de germinação (TMG) e porcentagem de germinação.

\begin{tabular}{cccc}
\hline \multirow{2}{*}{ Parameters } & \multicolumn{2}{c}{ Flooded } & \multicolumn{2}{c}{ Upland forests } \\
\cline { 2 - 4 } & Botanical & Technological & Botanical \\
\hline EVI & $0.8 \pm 0.1 \mathrm{Ba}$ & $0.6 \pm 0.1 \mathrm{Ba}$ & $1.9 \pm 0.2 \mathrm{Aa}$ \\
IGT & $16.0 \pm 4.2 \mathrm{Aa}$ & $22.5 \pm 13.4 \mathrm{Aa}$ & $6.0 \pm 0.0 \mathrm{Bb}$ \\
AGT & $33.9 \pm 6.8 \mathrm{Ab}$ & $46.1 \pm 4.2 \mathrm{Aa}$ & $17.3 \pm 1.1 \mathrm{Ba}$ \\
Germination (\%) & $98.0 \pm 2.0 \mathrm{Aa}$ & $96.0 \pm 0.0 \mathrm{Aa}$ & $96.0 \pm 0.0 \mathrm{Aa}$ \\
\hline
\end{tabular}

Mean \pm S.D. followed by same capital letters for environments (Flooded or upland forests) and lower case letter for criteria of germination (botanical or technological) are not significant at P d” 0.05 using the Tukey test.

Média \pm D.P. seguidos por letra maiúscula mesmo para ambientes (florestas inundadas ou de sequeiro) e letras minúsculas para o critério de germinação (botânica ou tecnológico) não são significativos a P d" 0,05, pelo teste de Tukey.

Revista Árvore, Viçosa-MG, v.34, n.6, p.1045-1053, 2010 
Table 2 - Starch, soluble sugars, lipids, and proteins content in assai palm seeds collected from plants in flooded and upland forests environments, before (quiescent) and after 75 days of germination (germinated).

Tabela 2 - Conteúdo de amido, açúcar solúvel, lipídios e proteínas em sementes de açaí coletadas de plantas em ambientes alagados e não alagados, antes (quiescente) e depois de 75 dias de germinação (germinadas).

\begin{tabular}{lcccr}
\hline Metabolites & \multicolumn{2}{c}{ Flooded } & \multicolumn{2}{c}{ Upland forests } \\
\cline { 2 - 5 } & Quiescent & Germinated & Quiescent & Germinated \\
\hline Starch (\%) & $75.9 \pm 7.9 \mathrm{Aa}$ & $75.2 \pm 4.0 \mathrm{Aa}$ & $54.6 \pm 2.2 \mathrm{Ba}$ & $33.5 \pm 0.7 \mathrm{Bb}$ \\
Soluble sugars (\%) & $1.3 \pm 2.3 \mathrm{Ba}$ & $1.8 \pm 2.8 \mathrm{Ba}$ & $3.9 \pm 6.9 \mathrm{Aa}$ & $3.7 \pm 3.4 \mathrm{Aa}$ \\
Lipids (\%) & $2.4 \pm 0.3 \mathrm{Aa}$ & $1.7 \pm 0.2 \mathrm{Aa}$ & $2.6 \pm 1.0 \mathrm{Aa}$ & $1.5 \pm 0.2 \mathrm{Aa}$ \\
Proteins (\%) & $4.4 \pm 0.3 \mathrm{Aa}$ & $0.9 \pm 0.1 \mathrm{Bb}$ & $4.7 \pm 0.5 \mathrm{Aa}$ & $1.0 \pm 0.1 \mathrm{Bb}$ \\
\hline
\end{tabular}

Mean \pm S.D. followed by same capital letters for environments (flooded or upland forests) and lower case letter for criterion of germination (quiescent or germinated) are not significant at P d" 0.05 using the Tukey test.

Média \pm D.P. seguidos por uma letra maiúscula mesmo para ambientes (sequeiro ou irrigado florestas) e letras minúsculas para o critério de germinação (quiescente ou germinadas) não são significativos a $P$ d" 0,05, pelo teste de Tukey.

$80 \%$ was observed in quiescent seeds (flooded and upland forests) when compared with germinated seeds. These results indicate that the reserves of nitrogen are probably in the form of proteins that come from degradation of storage proteins. Protein mobilization plays a major role as a source of nitrogen in the nutrition of the embryo during the germination of seeds of Euphorbia heterophylla as suggested by Suda and Giorgini (2000).

\subsection{Effect of oxygen deficiency on seedling growth}

As assai palm seeds did not germinate under anoxic conditions, we decided to test the influence of anoxic and normoxic conditions during early seedling growth. Analyses of storage (lipids, proteins, soluble sugars, and starch) revealed that their mobilization were influenced by seed source (flooded and upland forests) and oxygen availability (Figure 1A-D). Lipid contents underwent progressive reduction 20 days after germination (Figure 1A). According to Perata et al. (1997), the mobilization of lipids in flooded plants is probably less effective for anaerobic respiration due to the high demand of oxygen necessary for this type of metabolism. For proteins, a reduction was observed until 5 days after germination, followed by an increase in all treatments after 20 days, with higher levels presented in seedlings produced from seeds collected in upland forests (Figure 1B).

Under normoxic conditions, the contents of soluble sugars in seedlings increased approximately 4.5 times by the end of the experiment (Figure 1C). Starch content levels tripled until 5 days after germination in seeds collected from upland forests, followed by a progressive reduction after 20 days (Figure 1D). One possible hypothesis to explain the mobilization of starch might be related to a higher demand of carbohydrates due to higher growth rates observed. This probably increased the survival of seedlings under conditions of limited oxygen availability (Guglielminetti et al., 1995). Our observations are consistent with the fact that assai palm seedlings display some tolerance to flooding, which is probably associated with starch mobilization. In a study of different cereal species, Perata et al. (1997) found that rice seeds were the only ones capable of mobilizing starch under anoxic conditions. Furthermore, the accumulation of soluble sugars in developing seedlings under anoxic conditions is likely to be important for ATP production (Rodrigues et al., 2005).

According to Kolb et al. (2002), in Neotropical plant species, constitutive parameters of seeds such as size, nature and amount of reserves only partly influence resistance to flooding whereas parameters related to metabolic efficiency under stress conditions appear to be more important.

The ADH activity was assayed during early-seedling growth of the assai palm under aerobic (control) and anaerobic conditions (total and partial flooding) (Figure 2). After 2 days, ADH activity was strongly induced in seedling leaves growing under partial flooding conditions, whereas under complete flooding ADH activity remained high for 4 days (an increase of approximately 18 times). Subsequently, ADH activity was drastically reduced to levels similar to those observed in the control (Figure 2A). In comparison to the leaves, $\mathrm{ADH}$ activity in the roots was only weakly induced, being the highest level observed in roots under total flooding after 2 days (Figure 2B).

Revista Árvore, Viçosa-MG, v.34, n.6, p.1045-1053, 2010 

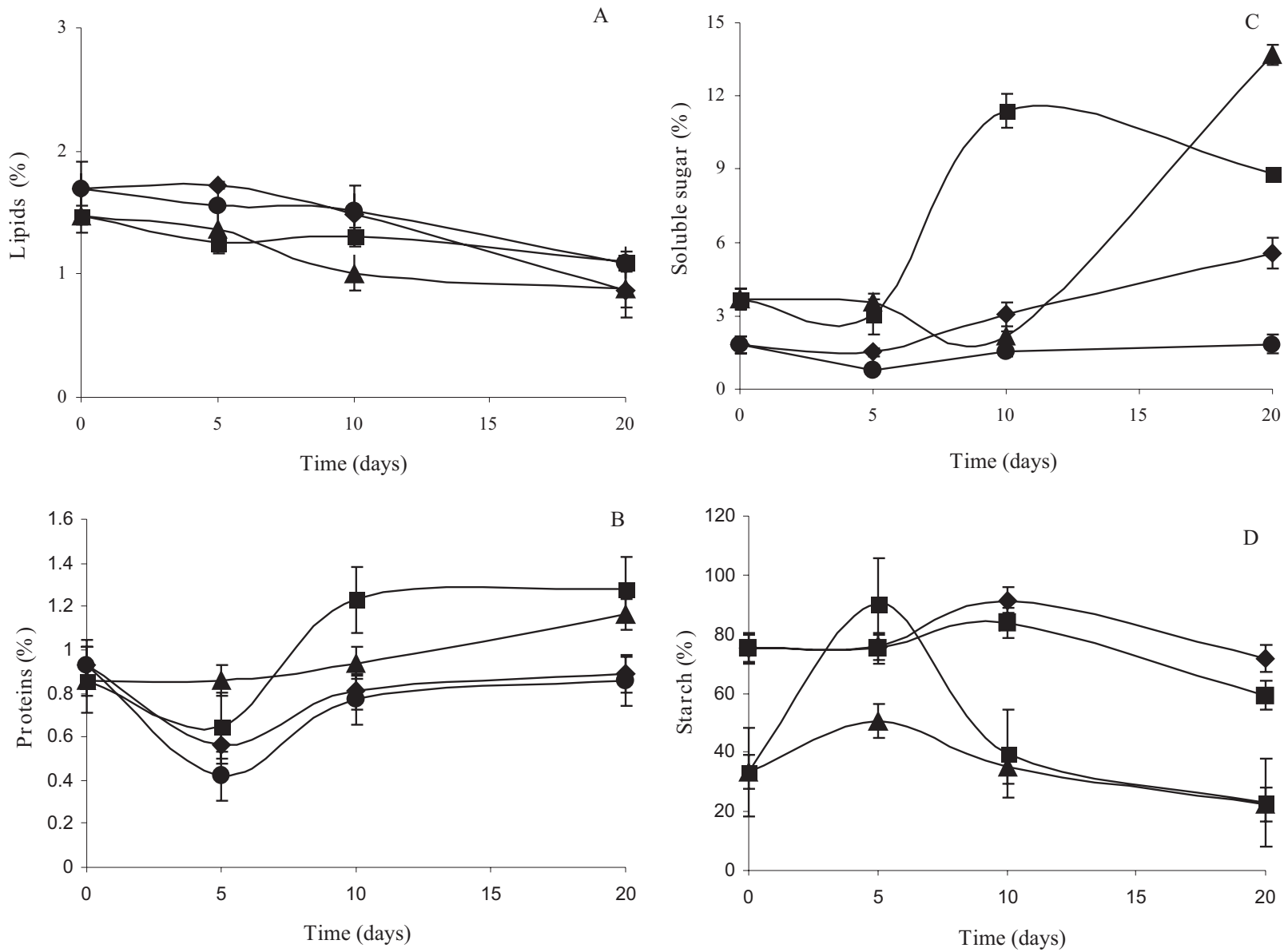

Figure 1 - Variation in the levels of lipids (A), proteins (B), soluble sugars (C), and starch (D), in quiescent (0) and germinated seeds (after 75 days) of the assai palm after 5, 10 and 20 days of seedling growth, collected from plants growing in the following environments: flooded control $(\diamond)$, plants from the flooded that were experimentally flooded $(\boldsymbol{O})$, upland forests control $(\boldsymbol{\Delta})$ and upland forests with flooding ( $\boldsymbol{\square})$.

Figura 1 - Variação nos níveis de lipídios (A), proteínas (B), açúcar solúvel (C) e amido (D), em sementes quiescentes (0) e germinadas (depois de 75 dias) de açaí após 5, 10 e 20 dias de crescimento da plântula, coletadas de plantas crescidas em ambientes: flooded control $(>)$, plants from the flooded that were experimentally flooded ( $)$, upland forests control ( $\boldsymbol{\Delta}$ ) and upland forests with flooding ( $\mathbf{(})$.

After 4 days, ADH activity in the leaves reduced to levels similar to those of the control group. High levels of ADH activity in plants under anaerobiosis have been associated with tolerance to flooding in plants (Liao and Lin, 2001). In Echinochloa crus-galli seedlings growing under anoxia the activity of enzymes associated to anaerobic metabolism (including ADH) increased 1.5-30 fold compared to their activity under aerobic conditions (Fukao et al., 2003). According to
Souza and Sodek (2002), the increase in the ADH activity in response to anoxia contributed to the maintenance of ATP synthesis guaranteeing seedling survival.

Our results indicate that seed germination and seedling growth display features that are compatible with a certain degree of tolerance to flooding, suggesting that the assai palm is quite well adapted to the Amazonian environmental conditions regarding the changes in water levels in the region. 


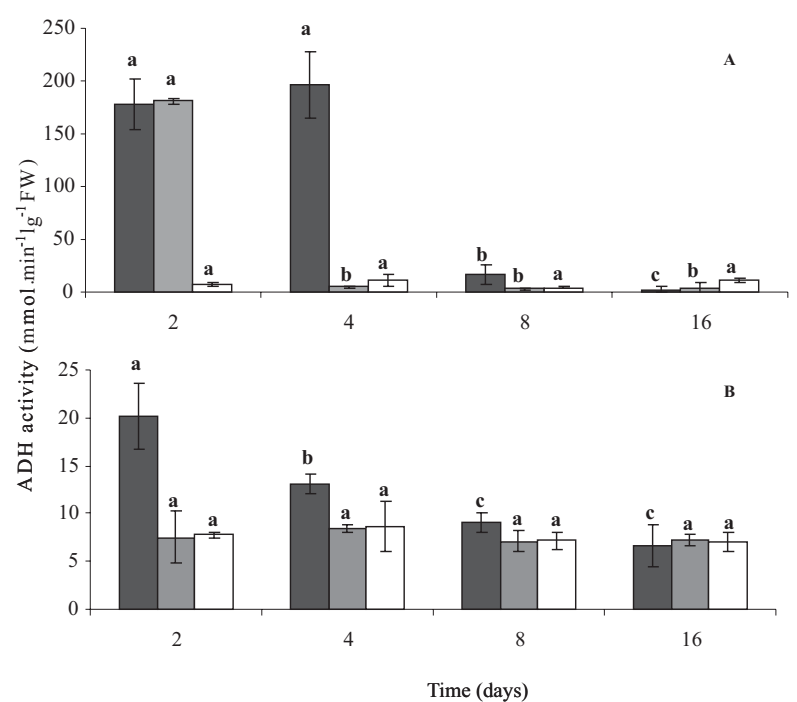

Figure 2 - Alcohol dehydrogenase (ADH) activity in the leaves (A) and roots (B) of assai palm seedlings cultivated during 2, 4, 8 and 16 days. Plant material was obtained from plants growing in upland forests and maintained in the following treatments: flooding

( $\square$ ), partial flooding $(\square)$, and control $(\square)$.

Figure 2 - Atividade da enzima álcool desidrogenase $(A D H)$ em folhas (A) e raízes (B) de plântulas de açaí cultivadas durante 2, 4, 8 e 16 dias. O material foi obtido de plantas crescendo em ambientes não alagados e mantidos nos tratamentos: alagado ( $\square$ ), parcialmente alagado ( $\square$ ) e controle ( $\square)$.

\section{ACKNOWLEDGEMENTS}

The authors thank the National Institute of Amazonian Research and members of Laboratory of Plant Physiology and Biochemistry (MCT-INPA) for their technical assistance during the analysis. Financial support for this study was provided by the CAPES-PRODAD and FINEP-CTPETRO. J.F.C.GONÇALVES and M.S.BUCKERIDGE acknowledge a fellowship granted by the National Council for Scientific and Technological Development - CNPq.

\section{REFERENCES}

ASSOCIATION OF OFFICIAL ANALYTICAL CHEMISTS - A.O.A.C. Official methods of analysis. 15.ed. Washington, D. C.:1984.

ARRUDA, G.M.T. \& CALBO, M.E.R. Efeitos da inundação no crescimento, trocas gasosas e porosidade radicular da carnaúba (Copernicia prunifera (Mill.) H.E. Moore). Acta Botânica Brasílica 18 (2): 219-224, 2004.
BOVI, M.L.A., SPIERING, S.H. \& MELO, T.M. Temperaturas e substratos para germinação de sementes de palmiteiro e açaizeiro. In Anais do Segundo Congresso sobre Tecnologia de Sementes Florestais. Atibaia, São Paulo. p. 43,1989.

BRADFORD, M. M. 1976. A rapid and sensitive method for the quantification of microgram quantities of protein utilizing the principle of protein-dye binding. Analytical Biochemistry 72: 248-254, 1976.

BRASIL. Ministério da Agricultura e Reforma Agrária. Regras para análise de sementes. Brasília: CLAV/DNDV/SNAD/MA. 365p, 1992.

BRAY, A.B., BAYLEY-SERRES, J. \&

WERETILNYK, E. Responses to abiotic stresses. In Biochemistry \& Molecular Biology of Plants (B. Buchanan, W. Gruissem \& R. Jones eds).

American Society of Plant

Physiologists. USA. p. 1158-1203, 2000.

BUCKERIDGE, M. S. \& DIETRICH, S.M.C.

Mobilisation of the raffinose family

oligosaccharides and galactomannan in germinating seeds of Sesbania marginata Benth. (Leguminosae - Faboideae). Plant Science 117: 33-43, 1996.

BUCKERIDGE, M. S., SANTOS, H. P., TINÉ, M. A. \& AIDAR, M.P.M. Mobilização de Reservas. In: Germinação do básico ao aplicado. Alfredo Gui Ferreira \& Fabian Borgheti (Eds). Artmed, Porto Alegre p. 163-185, 2004.

CALBO, M.E.R.; MORAES, J.P.V. \& CALBO,A.G Crescimento, condutância estomática, fotossíntese e porosidade do buriti sob inundação. Revista Brasileira de Fisiologia Vegetal 10: 51-58, 1998.

CARVALHO, C.J.R. de \& ISHIDA, F.Y. Respostas de pupunheiras (Bactris gasipaes Kunth) jovens ao alagamento. Pesquisa Agropecuária Brasileira 37: 1231-1238, 2002.

CRAWFORD, R. M. M. Alcohol dehydrogenase activity in relation to flooding tolerance in roots. Journal of Experimental Botany 18: 458-464, 1967.

DOLFERUS, R., KLOK, E. J., DELESSEST, C., WILSON, S., ISMOND, K. P., GOOD, A. G., PEACOCK, W. J. \& DENNIS, E. Enhancing the anaerobic response. Annals of Botany 91: 111-117, 2003.

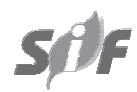

Revista Árvore, Viçosa-MG, v.34, n.6, p.1045-1053, 2010 
DREW, M. C. Oxygen deficiency and root metabolism: injury and acclimation under hypoxia and anoxia. Annual Review of Plant Physiology and Plant Molecular Biology 48: 223-250, 1997.

FEARNSIDE, P.M. Greenhouse gas emissions from a hydroelectric reservoir (Brazil’s Tucuruí Dam) and the energy policy implications. Water, Air and Soil Pollution 133: 69-96, 2002.

FIGUEIREDO, F.J.C., ROCHA-NETO, O.G. da \& CARVALHO, C.J.R. de. Mobilização de reservas na emergência e desenvolvimento de plântulas de cupuaçu (Theobroma gradiflorm). Revista Ciências Agrárias 36: 101-109, 2001.

FUKAO, T., KENNEDY, R.A., YAMASUE, Y. \& RUMPHO, M.E. Genetic and biochemical analysis of anaerobically-induced enzymes during seed germination of Echinochloa crus-galli varieties tolerant and intolerant of anoxia. Journal of Experimental Botany 386: 1421-1429, 2003.

GUGLIELMINETTI, L., YAMAGUCHI, J., PERATA, P. \& ALPI, A. Amylolitic activities in seeds under aerobic and anaerobic conditions. Plant Physiology 109: 1069-1076, 1995.

JUNK, W.J. Flood tolerance and tree distribution in Central Amazonian Floodpains. In Tropical Forests: Botanical Dynamics, Spenciantion and Diversity (L.B. Nielsen, I.C. Nielsen, \& H. Baslev, eds). Academic Press, London. p. 47-64, 1989.

JUNK, W. J. Wetlands of tropical South America. In Wetlands of the World (D.F. Whigham, S. Hejny \& D. Dykyjova eds). Kluwer Publishers, The Netherlands. p. 679-739, 1993.

KOLB, R.S., RAWYLER, A. \& BRAENDLE, R. Parameters affecting the early seedling development of four Neotropical trees under oxygen deprivation stress. Annals of Botany 89: 551-558, 2002.

LABOURIAU, L.G. A germinação das sementes. OEA: Washington, 174p, 1983.

LIAO, C.T. \& LIN C.H. Physiological adaptation of crop plants to flooding stress. Proclation National Science Council 3: 148-157, 2001.
MENEZES NETO, M.A., ALVES J.D. \& OLIVEIRA, L.E.M. Anaerobic metabolism of Euterpe oleracea. II-Plant tolerance mechanism to anoxia. Revista Brasileira de Fisiologia Vegetal 7 (1): 47-51, 1995.

MORAES, M. G. ; ALVES, J. D. OLIVEIRA, L. E. M. de. Efeitos da anaerobiose induzida por alagamento em plântulas de seis espécies herbáceas. Ciência e Agrotecnologia, Lavras, 25: 941-951, 2001.

MORRIS, D.L. Quantitative determination of carbohydrates with Drewood's anthrone reagent. Science 107: 254-255, 1948.

OKAMOTO, J.M. \& JOLY, C.A. Ecophysiology and respiratory metabolism during the germination of Inga sessilis (Vell.) Mart. seeds subjected to hipoxia and anoxia. Revista Brasileira de Botânica 23: 51-57, 2000.

OLIVEIRA, M.S.P. do, CARVALHO, J.E.U. de, NASCIMENTO, W.M.O. \& MULLER, C.H. Cultivo do Açaizeiro para Produção de Frutos. Circular Técnica - EMBRAPA, Belém, PA, Junho, 2002.

PAROLIN, P., SIMONE, O., HAASE, K., WALDHOFF, D., ROTTENBERGER, S., KUHN, U., KESSELMEIER, J., SCHMIDT, W., PIEDADE M.T.F.and JUNK W.J. Central Amazon floodplain forests: tree survival in a pulsing system. The Botanical Review 70, pp. 357-380, 2004.

PASSOS, L.P. Métodos Analíticos e Laboratoriais em Fisiologia Vegetal. 1996. Coronel Pacheco: Embrapa Gado de Leite.

PERATA, P., GUGLIELMINETTI, L. \& ALPI, A. Mobilization of endosperm reserves in cereal seeds under anoxia. Annals of Botany 79: 49-56, 1997.

PONTES, A.C., BORGES, E. E. De L., BORGES, R de. C. G. \& SOARES, C. P. B. Mobilização de reservas em sementes de Apuleia leiocarpa (Vogel) J. F. Macbr. (Garapa) durante a embebição. Revista Árvore 26: 593-601, 2002.

RICARD, B., COUEÉ, I., RAYMOND P., SAGLIO, P. H., SAINT-GES, V. \& PRADET, A. Plant metabolism under hypoxia and anoxia. Plant Physiology and Biochemistry 32: 1-10, 1994. 
RODRIGUES, M.O. de; CREPALDI, I.C.; LUCHESE, A. M.; CARVALHO, N. O. S.; BRITO, A.L.; PELACANI, C.R. \& LEDO, C. A. Influência do armazenamento nos teores de açúcares solúveis totais e redutores em sementes de Syagrus coronata (Martius) Beccari (Arecaceae). Sitientibus Série Ciências Biológicas 5: 72-75, 2005.

SOUZA, C.A.F. de \& SODEK, L. The metabolic response of plants to oxygen deficiency. Brazilian Journal of Plant Physiology 14: 83-94, 2002.

SUDA, C. N. K. \& GIORGINI, J. F. 2000. Seed reserve composition and mobilization during germination and initial seedling development of Euphorbia heterophylla. Revista Brasileira de Fisiologia Vegetal 12: 226-245, 2000.
WALDHOFF, D., JUNK, W.J. \& FURCH, B. Responses of three Central Amazonian tree species to drought and flooding under controlled conditions. International Journal of Ecology and Environmental Sciences 24: 237-252, 1998.

WIGNARAJAH, K, GREENWAY, H. AND JOHN, C.D. Effect of water logging on growth and activity of alcohol dehydrogenase in barley and rice. New Physiologist 77: 585-592, 1976.

WITTMANN, A. O; PIEDADE, M. T. F; PAROLIN, P; WITTMANN, FLORIAN. Germination of four low-varzea tree species in central Amazonia. Aquatic Botany, v. 86, p. 197-203, 2007. 